\title{
NUTRIENT DEPLETION IN WESTERN FLOWER THRIPS AFFECTS THEIR RESPONSE TO ODOUR AND VISUAL CUES
}

\author{
M.M. DAVIDSON, R.C. BUTLER and D.A.J. TEULON \\ Crop \& Food Research, Private Bag 4704, Christchurch, New Zealand \\ Corresponding author: davidsonm@crop.cri.nz.
}

Nutrient depletion through starvation is known to affect an insect's behaviour. The aim of this study was to examine the effects of starvation on the walking or flying response of adult female Western flower thrips to visual and/or odour cues in two types of olfactometer. A Y-tube olfactometer was used to restrict the movement of thrips starved for 0 or $24 \mathrm{~h}$, to walking, in response to an odour cue (1 $\mu \mathrm{l}$ of $10 \%$ p-anisaldehyde). Thrips, starved for $0,24,48$ or $72 \mathrm{~h}$, were able to fly in response to a visual cue $\left(98 \mathrm{~cm}^{2}\right.$ yellow sticky trap) and/or odour cue ( $0.5 \mathrm{ml}$ p-anisaldehyde) in a wind tunnel olfactometer. In the Y-tube experiments more thrips walked up the odour-laden arm when starved for $24 \mathrm{~h}(77.3 \%)$ than those not starved $(58.7 \%)$. In the wind tunnel experiments the percentage of thrips to fly (regardless of cue) or land on a yellow sticky trap changed significantly with starvation period $(\mathrm{P}<0.001)$, increasing markedly between $0(6 \%$ to fly, $3 \%$ on trap) and $24 \mathrm{~h}$ ( $72 \%$ to fly, $36 \%$ on trap) and decreasing slightly between 48 (75\% to fly, $39 \%$ on trap) and $72 \mathrm{~h}$ (57\% to fly, $30 \%$ on trap).

\section{PHENOLOGY OF NEW ZEALAND FLOWER THRIPS (THRIPS OBSCURATUS) IN VINEYARDS}

\author{
K. SCHMIDT ${ }^{1}$, D.A.J. TEULON ${ }^{2}$, M-C. NIELSEN ${ }^{2}$, S.D. WRATTEN ${ }^{1}$ \\ and M.V. JASPERS ${ }^{1}$
}

\author{
${ }^{1}$ National Centre for Advanced Bio-Protection Technologies, PO Box 84, \\ Lincoln University, Canterbury \\ ${ }^{2}$ Crop \& Food Research, Private Bag 4704, Christchurch, New Zealand \\ Corresponding author: schmidtk@lincoln.ac.nz.
}

The New Zealand Flower Thrips (NZFT), Thrips obscuratus Crawford, a thrips species endemic to New Zealand, is widespread in vineyards at flowering. During spring, thrips eggs, larvae and adults are abundant on many flowering plants and this species can achieve a density of up to two million per hectare in vineyards. In wine grapes, thrips are considered to cause little direct economic damage. However, they have been shown to vector diseases, therefore they may also vector Botrytis cinerea, the cause of Botrytis bunch rot. The first step in investigating the interactions between the fungus and the insect was to study the population dynamics of the thrips in vineyards. At two vineyard field sites (Nelson and Canterbury), aerial populations of adult NZFT were monitored from spring to autumn. White water traps at three different heights were placed throughout the vineyard and emptied weekly. Additionally, a $7.5 \mathrm{~m}$ high suction trap (based on the Johnson-Taylor trap) was placed close to the Canterbury site to monitor local flight activity. The first data on thrips numbers are presented here. This work is part of a wider study, which will be conducted over the next two years, to quantify interactions between NZFT and B. cinerea. 